\title{
Tinjauan Awal \\ Bangunan Rumah Tinggal Kolonial \\ Kawasan Simpang Surabaya
}

\author{
Delta Bayu Murti \\ Departemen Antropologi \\ Fakultas Ilmu Sosial dan Ilmu Politik Universitas Airlangga \\ Email: d.bayumurti@gmail.com
}

\begin{abstract}
Abstrak: Tujuan studi ini membahas keberadaan bangunan rumah tinggal kolonial Belanda yang ada di kawasan Simpang Surabaya. Metode pengumpulan data dalam studi ini adalah survei arkeologis, melalui pengamatan, perekaman dan dokumentasi foto. Hasil identifikasi dari aspek arsitektur mengindikasikan rumah tinggal kolonial yang didokumentasi bergaya arsitektur sebelum 1900, arsitektur transisi, dan arsitektur modern. Selain itu didokumentasipula kerusakan dan perubahan pada bangunan rumah tinggal kolonial yang ada, yang terindikasi berkaitan dengan statusnya sebagai bukan cagar budaya dan perkembangan kawasan Simpang sendiri.
\end{abstract}

Kata kunci: Surabaya, kawasan Simpang, rumah tinggal kolonial, arsitektur

\begin{abstract}
The aim of this study is to discuss the existence of the Dutch colonial resicende in Simpang district Surabaya. Method applied in this study is archaeological survey, i.e. observation, recording and photo documentation. The identification results from architectural aspects of colonial residence indicated architecture style before 1900 , transition architecture, and modern architecture. It also documented the damage and changes to the existing of colonial residential buildings, which is indicated to relate with its exclusion from cultural heritage status and the development of Simpang district itself.
\end{abstract}

Keywords: Surabaya, Simpang district, colonial residence buildings, architecture

\section{Latar Belakang}

Berbagai fasilitas bangunan dalam suatu kawasan, pola tata ruang, dan faktor penting lain yang kemudian membentuk sebuah kota, sesungguhnya adalah bentuk adaptasi dari perkembangan ekonomi, sosial, dan budaya yang menjadi bagian dari kehidupan kota. Demikian halnya dengan bangunan masa kolonial. Di kota-kota besar di Indonesia, seperti Jakarta, Semarang, Surabaya, atau Malang, bangunan-bangunan dengan latar belakang masakolonial (Belanda) dapat dengan mudah ditemukan. Bangunan-bangunan itu merupakan gambaran sejarah, bagaimana sebuah kota mengalami perkembangan dan kemajuan. Karena itulah bangunan-bangunan masa kolonial dalam perkembangannyamenjadi salah satu warisan sejarah dan budaya yang bernilai tinggi.

Surabaya adalah salah satu kota besar di Indonesia yang memiliki banyak sumberdaya sejarah dan budaya berupa bangunan masa kolonial.Keberadaan bangunan tersebuttidak dapat dilepaskan dari sejarah perkembangan kotanya. Surabaya sendiri mulai berkembang sekitar akhir tahun 1700,dari kota bergaya kuno menjadi kota bergaya Eropa. Perkembangan berikutnya yaitu setelah tahun 1870 yang dianggap sebagai perkembangan baru era kolonial Belanda, dan dijelaskan pula sebagai masa modernisasi kota Surabaya (Handinoto \& Hartono, 2007; Kwanda, 2005). Beberapa faktor pendorong perkembangan kota Surabaya setelah tahun 1870 adalah dihapuskannya Cultuurstelsel (Kwanda, 2005), adanya Undang-undang Gula (Suikerwet) dan Undang-Undang Agraria (Agrarischewet) pada tahun 1870, serta dibongkarnya benteng yang mengelilingi Surabaya sekitar tahun 1871 sebagai bagian dari rencana perluasan dan pengembangan kota (Handinoto, 1998, 2012). Jaringan transportasi yang juga dikembangkan di Surabaya setelah tahun 1870 kemudian memunculkan pola baru pada struktur kotanya, yaitu adanya pembedaan antara pusat bisnis dan pusat permukiman (Handinoto \& Hartono, 2007).

Salah satu pusat permukiman dalam sejarah perkembangan kota Surabaya adalah kawasan Simpang. Simpang umum dikenal sebagai nama salah satu jalan di Surabaya. Widodo (2008) menjelaskan bahwa Jalan Simpang (Simpangstraat) adalah sebuah jalan yang memanjang dari ujung Jalan Tunjungan sampai ujung Jalan 
Kayun (Kayoonstratt). Tepat di bagian tengah Jalan Simpang dipisahkan oleh Jalan Yos Sudarso (Dijkermanstraat) dan Jalan Panglima Sudirman (Palmenlaan) (Gambar 1.).

Simpang pada masa pemerintahan kolonial merupakan kawasan yang diperuntukkan bagi permukiman orang-orang Belanda atau Eropa di Surabaya. Di kawasan ini, pola permukiman atau hunian penduduknya terutama berada di sepanjang ruas jalan utama dan sepanjang sisi kiri atau kanan Sungai Kalimas. Pola tersebut disesuaikan dengan rencana awal perluasan kota Surabaya,yaitu pengembangan sistem radial dengan membangun perumahan dan gedung bangunan lain di sepanjang jalan utama kota. Bentuk permukiman di kawasan Simpang secara umum dipengaruhi oleh perkembangan bentuk struktur kota yang mengikuti aliran sungai sebagai jaringan utama transportasi (utara ke selatan) (Handinoto \& Hartono, 2007). Soekiman (2014) pun menegaskan bahwastruktur kota yang mengikuti aliran sungai menjadi pola umum perkembangan kotakota pelabuhan di Jawa pada masa kolonial.

Pertumbuhan dan perkembangan kota-kota di Indonesia yang pesat dan dinamis, termasuk Surabaya, dalam lima dekade terakhir tampaknya membawa pengaruh pada keberadaan bangunan masa kolonialyang bernilai historis. Salah satupermasalahan yang banyak ditemukan adalah bangunan masa kolonial dirobohkan untuk diganti dengan bangunan baru,berkaitan dengan perubahan fungsi bangunan dan karakter kawasan serta aktivitas masyarakat yang ada dalam suatu kawasan(Kwanda, 2005). Telah dijelaskan pula olehSulyanto (2003) bahwa permasalahanseperti itu merupakan fenomena yang umum terjadi di kota-kota yang berkembang dengan model Eropa atau kolonial, di Indonesia maupun di negara lain.

Sebagai salah satu kawasan permukiman pada masa kolonial, Simpang juga tidak lepas dari pengaruh perkembangan kota Surabaya mengikuti modernisasi. Rumah tinggal sebagai penciri penting sejarah perkembangan kawasan, terutama yang dibangun pada masa kolonial, semakin berkurang jumlahnya. Berbagai sumber tertulis yang dikumpulkan menjelaskan bahwa ternyata kawasan Simpang dan rumah tinggal yang dibangun pada masa kolonial bukan bagian dari cagar budaya.

Tulisan ini akan membahas mengenai

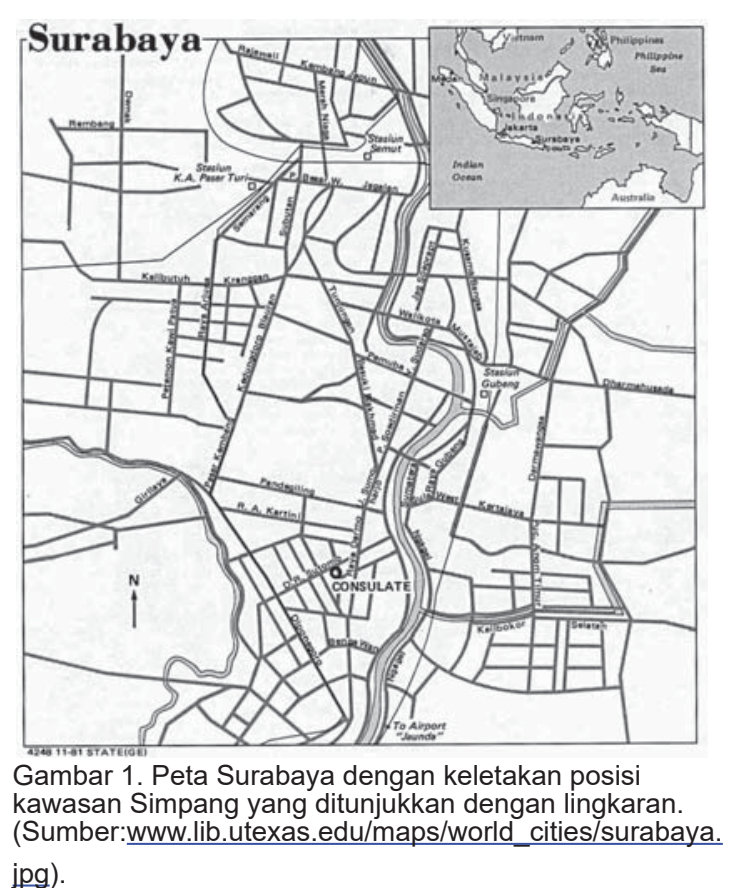

keberadaan bangunan rumah tinggal masa kolonial yang ada di kawasan Simpang. Tujuan penelitian ini adalah mengumpulkan data mengenai bangunan rumah tinggal masa kolonial yang masih tersisa di kawasan Simpang.

\section{Bahan dan Metode}

Bahan studiadalah bangunan rumah tinggal yang ada di kawasan Simpang Surabaya. Secara administratif kawasan Simpang termasuk dalam wilayah Kecamatan Genteng, Surabaya Pusat. Bangunan rumah tinggal yang menjadi bahan studiterutama beradadijalan Kayun, Jalan Embong Kenongo, Jalan EmbongTanjung, Jalan Embong Ploso, dan Jalan Embong Kemiri.

Pengumpulan data bangunan rumah tinggal di kawasan Simpang dilakukan melalui survei lapangan. Survei adalah salah satu metode yang digunakan dalam arkeologi untuk pengumpulan data. Kegiatan kerja yang dilakukan adalah pengamatan pada objek penelitian dari jarak dekat. Cara tersebut digunakan untuk mendapat data arkeologi dalam konteks lingkungan sekitarnya, termasuk hubungan antar data arkeologi yang ada pada suatu wilayah (Sukendar dkk., 1999).

Surveibangunan rumah tinggal di kawasan Simpang dilakukan dengan observasi langsung pada lokasi yang telah ditentukan, kemudian dilakukan perekaman terhadap kondisi bangunan rumah tinggal, lingkungan dan beragam perubahan yang menyertai, serta dilakukan pendokumentasian melalui foto. Survei awal untuk studi ini telah dilakukan pada tahun 2010, dan dilakukan 
survei ulang pada tahun 2015. Rumah tinggal kolonial di kawasan Simpang diidentifikasi berdasarkangaya arsitektur bangunan mengacu pada studi Handinoto (1996, 2012). Data tambahan lain dikumpulkan melalui studi literatur, yang digunakan sebagai pembanding data observasi.

\section{Hasil dan Pembahasan}

\section{Rumah Tinggal di Kawasan Simpang}

Sebanyak 16 bangunan rumah tinggal didokumentasi selama proses survei pada tahun 2010 dan 2015 (Tabel 1.). Bangunan-bangunan ini dipilih berdasarkan tampak luar yang masih/menunjukkan ciriciri bangunan masa kolonial. Pada survei tahun 2010 perekaman dan pendokumentasian terfokus ke bangunan dengan kondisi yang relatif utuh. Survei tahun 2015 menambahkan bangunan dengan kondisi mengalami kerusakan atau mendekati perobohan.

Survei disepanjang Jalan Kayun pada tahun 2010 tercatat empatrumah tinggal dengan arsitektur kolonial. Survei ulang pada tahun 2015 mendapati salah satu rumah telah mengalami pembongkaran (tahun 2013), yaitu rumah no. 4-6 yang ada di sisi ujung utara Jalan Kayun. Rumah inipernah menjaditempat peribadatan umat Yahudi (Sinagoge) di Surabaya (Gambar 2.).Tiga rumah lainnya masih dalam kondisi terawat baik, yaitu rumah di Jalan Kayun no. 16-18 yang digunakan sebagai gedung Museum Kanker Indonesia (Gambar 3a.), dan rumah dengan no. 32. Berikutnya rumah no. 42-44, merupakan salah satu rumah tinggal yang telah diinventarisasi oleh Pemerintah Kota Surabaya sebagai bangunan cagar budaya (Gambar 3b.). Arsitek yang merancang rumah tinggal ini adalah G. C. Citroen (1881-1935) dan dibangun pada tahun 1928 (Handinoto, 1993;Widodo, 2008).

Tabel 1. Jumlah bangunan rumah tinggal yang menjadi obyek studi

\begin{tabular}{|lll} 
No & Nama Jalan & Jumlah \\
\hline 1 & Kayun & 5 \\
\hline 2 & Embong Kenongo & 1 \\
\hline 3 & Embong Tanjung & 3 \\
\hline 4 & Embong Ploso & 3 \\
\hline 5 & Embong Kemiri & 4 \\
\hline
\end{tabular}
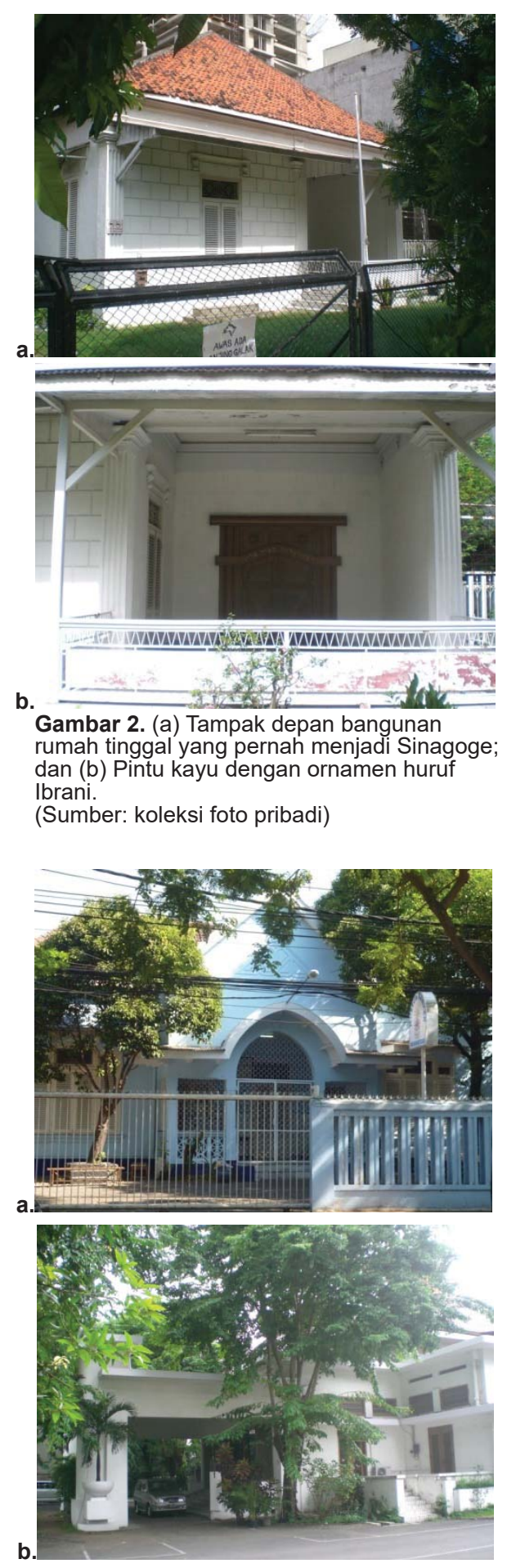

Gambar 3. (a) Tampak depan rumah tinggal yang menjadi Museum Kanker;

(b) Bagian depan bangunan rumah tinggal

karya G. C. Citroen dilihat dari sisi kiri.

(Sumber: koleksi foto pribadi)

Survei berikutnya dilakukan di Jalan Embong Kenongo. Pada tahun 2010 di jalan ini tercatat satu buah rumah tinggal dengan arsitektur kolonial(Gambar 4a.). Survei ulang tahun 2015 mendapati satu-satunya bangunan rumah tinggal yang ada itu telah berganti menjadi bangunan dengan arsitektur baru.Survei berikutnya di Jalan Embong Tanjung mencatat tiga rumah 
tinggal.Pertama adalah rumah no. 24-28, dengan kondisi terawat baik (Gambar 4b.). Berikutnya adalah rumah tinggal dengan no. 27-29. Berdasarkan data dokumentasi survei tahun 2010, terdapat sedikit perubahan di halaman depanrumah tinggal ini (Gambar 5a.), tetapi secara umum kondisi rumah tidak berubah dan terawat baik.Terakhir adalah rumah tinggal dengan no. 33 dengan kondisi yang juga masih terawat baik (Gambar 5b.).

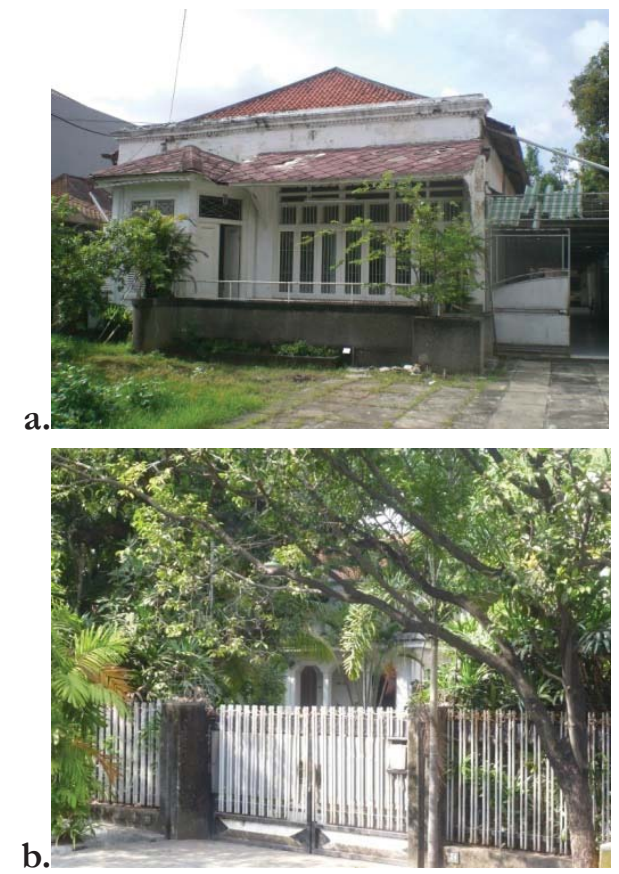

Gambar 4.(a) Rumah tinggal di Jalan Embong Kenongo pada tahun 2010.

(b) Rumah Jalan Embong Tanjung no.24-28 dengan bagian depan tertutup pepohonan. (Sumber: koleksi foto pribadi)
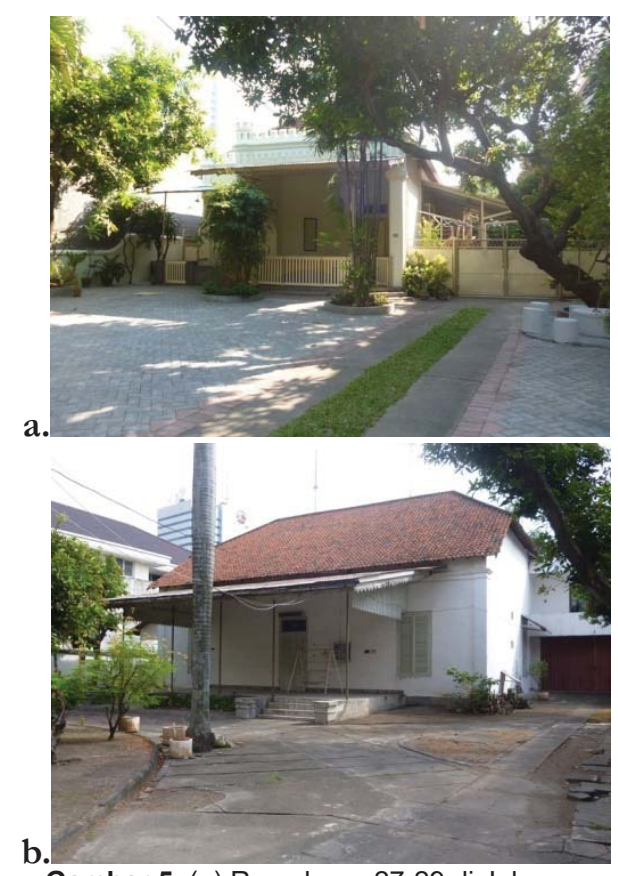

Gambar 5. (a) Rumah no. 27-29 di Jalan Embong Tanjung

(b) Tampak depan rumah di Jalan Embong Tanjung no. 33 .

(Sumber: koleksi foto pribadi)
Dijalan Embong Ploso, survei tahun 2010 mencatat tiga rumah tinggal dengan arsitektur kolonial. Pertama adalah rumah dengan no. 2-4 yang berada di bagian barat jalan. Berikutnya rumah dengan no. 19 (Gambar 6a.). Informasi yang telah diperolehdari survei tahun 2010, rumah ini dibangun pada tahun 1912 dengan sertifikat hak milik yang dikeluarkan oleh pemerintah kolonial Belanda pada waktu itu (personal communication). Survei ulang yang dilakukan tahun 2015 mendapati perubahan yang terjadi pada rumah no. 19 ini. Pagar depan rumah yang semula dari bahan kawat besi rendah, telah berganti dengan pagar beton tinggi. Jika dilihat dari luar pagar rumah, tampaknya tidak terdapat perubahan besar (Gambar 6b.). Selain tiga rumah yang terawat baik itu, di Jalan Embong Ploso juga terdapat satu rumah di ujung timur jalan (juga berada di sepanjang jalan Kayun) dengan kondisi rusak dan tertutup pagar seng (Gambar 7a. dan 7b.).

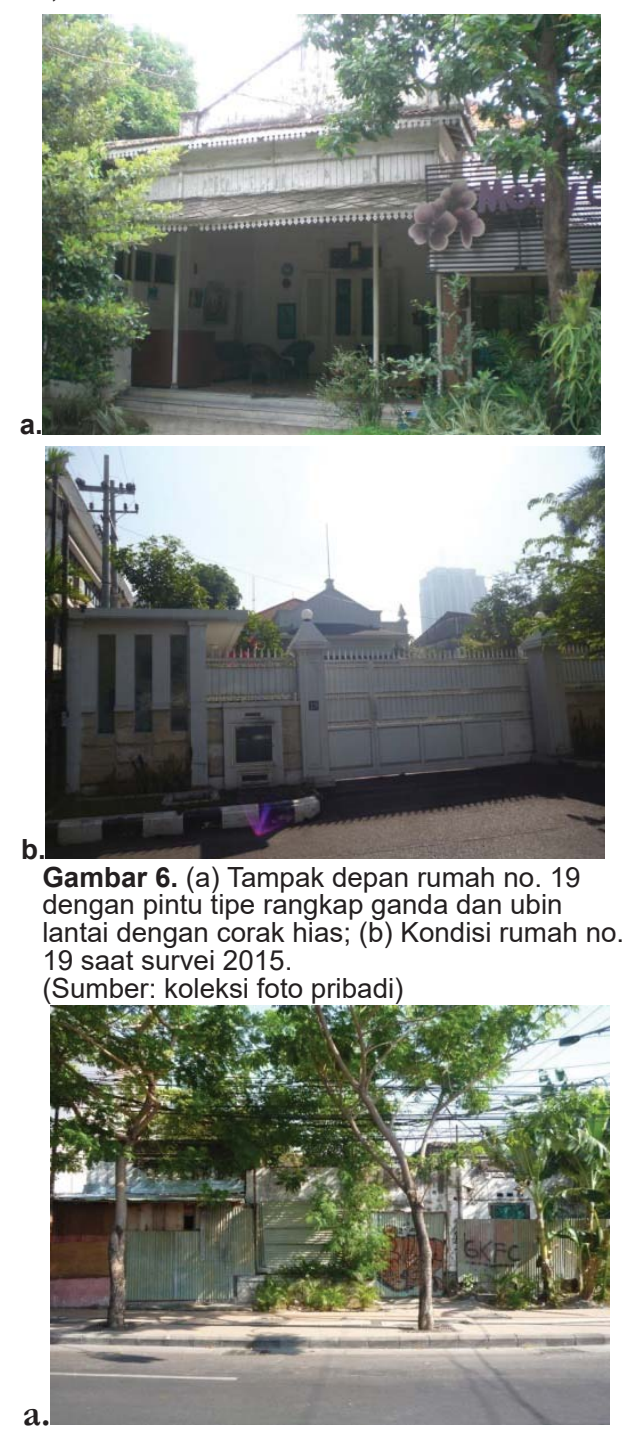




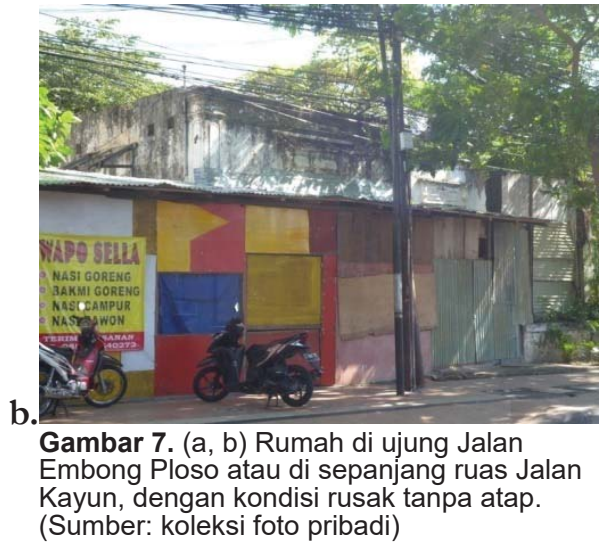

Survei yang dilakukan di Jalan Embong Kemiri dicatatempat rumah tinggal. Pada rumah tinggal pertama di sisi paling barat(tidak diketahui nomer rumah) kondisi rumah terlihat terawat baik. Pada rumah tinggal kedua, yaitu rumah dengan no. 17, kondisinyacukup terawat (Gambar 8a.).Pada tahun 2010 rumah tersebut masih dalam proses penawaran untuk dijual (Gambar 8b.). Survei ulang tahun 2015 mendapati kondisi rumah masih terlihat sama seperti hasil survei tahun 2010 (Gambar 10a.). Dua rumah terakhir didapati berada dalam kondisi yang tidak terawat. Pada bagian depan pagar tertutup oleh lembar besi/seng. Kedua rumah tinggal ini merupakan hak milik dari PT. PAL Indonesia (survei 2010) (Gambar 9a. dan 9b.). Survei ulang tahun 2015 mendapati kedua rumah ini mengalami kerusakan, terutama di bagian atap rumah (Gambar 10b).

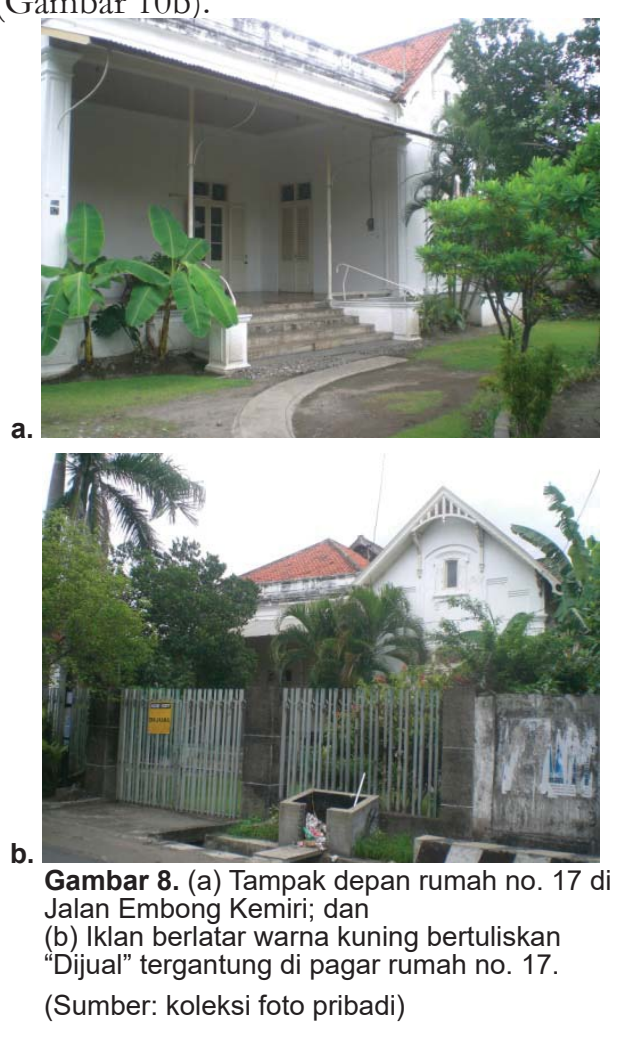

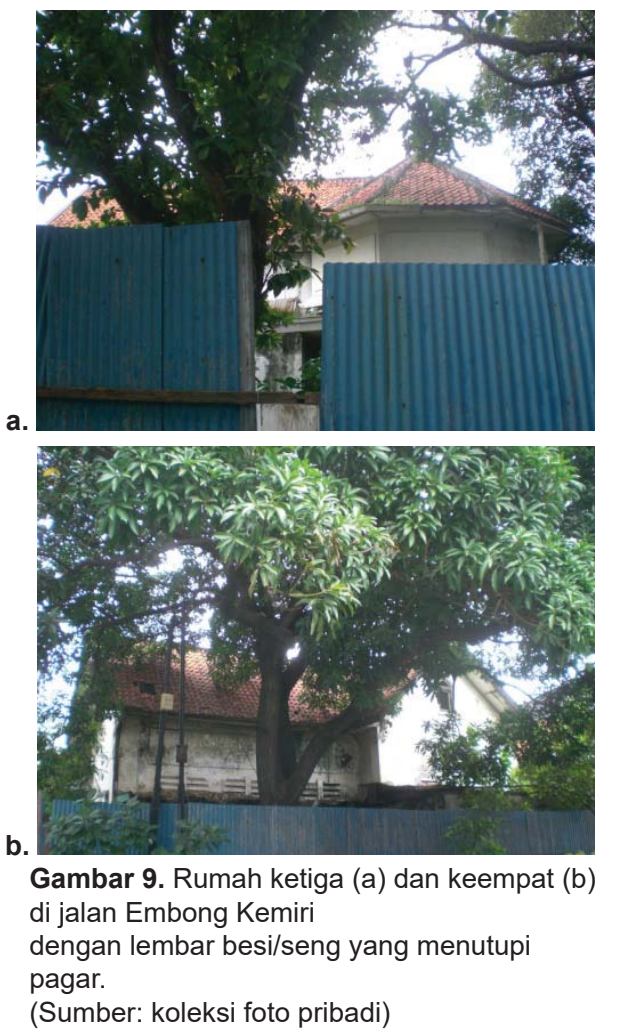

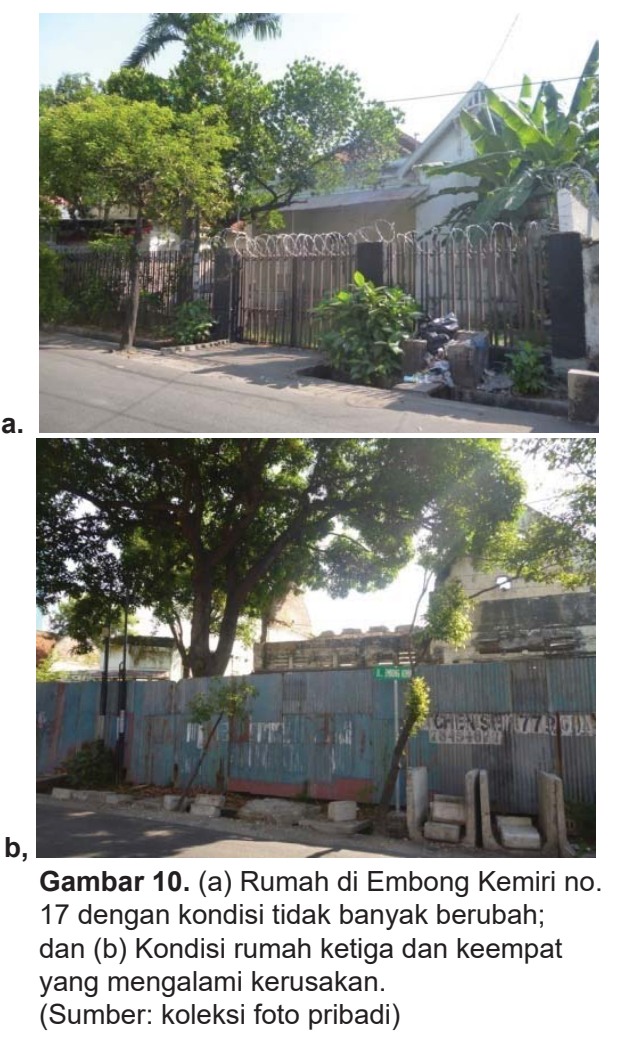

\section{Arsitektur Bangunan Rumah Tinggal}

Bangunan kolonial identik dengan arsitektur yang berkembang selama masa pemerintahan kolonial Belanda. Arsitektur kolonial, demikian umum disebut, merupakan hasil akulturasi melalui sebuah proses adaptasi. 
Dalam hal ini proses adaptasi mencakup perbedaan iklim, ketersediaan material, teknik pembangunan, dan juga seni-budaya yang berkaitan dengan faktor estetikadi Indonesia dan kemudian berakulturasi dengan budaya asing Belanda/Eropa (Sooekiman, 2014).

Bangunan dengan arsitektur kolonial salah satunya adalah bangunan rumah tinggal. Sebagai salah satu unsur penting dalam perkembangan permukiman, rumah tinggal merupakan kebutuhan utama. Dalam konstruksi bangunannya, unsur-unsur keamanan, keindahan, dan kenyamanan menjadi bagian penting untuk diperhatikan, yang juga disesuaikan dengan lingkungan, teknologi, dan perkembangan kehidupan sosial.Dari segi arsitektural, rumah tinggal merupakan bagian terkecil dalam perkembangan studi arsitektur (Karisztia dkk., 2008).

Di Indonesia, khususnya kota Surabaya, perkembangan arsitektur bangunan kolonialnya dapat dibagi menjadi tiga periodisasi (Handinoto, 1996), yaitu:

1. Antara tahun 1870 sampai tahun 1900

Gaya arsitektur berorientasi ke aliran neo klasik yang berkembang di Eropa, terutama di negara Perancis. Di Hindia Belanda gaya neo klasik ini diterjemahkan secara bebas, yang kemudian dikenal dengan nama The Empire Style (The Dutch Colonial Villa). Gaya arsitektur Empire Style terutama berkembang pada rumah-rumah orang Belanda (landhuis). Ciri-ciri gaya arsitektur Empire Style yaitu denah simetris satu lantai dan ditutup atap perisai, karakteristik bangunannya terbuka, pilar (bergaya Yunani) di serambi depan dan belakang, terdapat serambi tengah (di dalam rumah), dan terdapat gevel serta mahkota di atas serambi depan serta belakang.

2. Setelah tahun 1900

Bentuk arsitektur yang berkembang sesudah tahun 1900 ini lebih spesifik, sebagai hasil adaptasi arsitektur modern yang berkembang di Belanda dengan iklim tropis basah di Indonesia. Adaptasi menghasilkan bentuk khas, berbeda dari arsitektur modern yang ada di Belanda. Beberapa faktor pendukung perkembangan gaya arsitektur ini adalah sistem organisasi pembangunan yang makin disempurnakan (diatur oleh BOW, sejenis Dinas Pekerjaan Umum), dan peningkatan profesionalisme dengan detil perancangan yang lebih baik. Beberapa elemen arsitektur yang banyak berkembang pada masa setelah 1900-1920 yaitu:

- Gevel(pada tampak depan bangunan),
- Tower(kadang-kadang ujungnya diberi atap atau dikombinasikan dengan gevel depan),

- Dormer,

- Ventilasi (pembukaan untuk aliran udara),

- Bentuk bangunan yang ramping dan menghindari orientasi timur-barat, dan

- Galeri (digunakan pada sepanjang bangunan untuk antisipasi hujan dan matahari).

3. Setelah tahun 1920

Aliran yang berpengaruh pada periode ini adalah arsitektur modern. Beberapa ciri utama pada bangunannya yaitu warna putih, atap datar, gevel horizontal, dan volume bangunan kubus.

Di kawasan Simpang yang menjadi lokasi studi ini, gaya arsitektur bangunan dari masing-masing periode perkembangan arsitektur kolonial di Surabayajuga dapat diamati pada beberapa rumah tinggal yang menjadi bahan studi. Gaya arsitektur dari periode 1870-1900 tampak pada rumah tinggal di Jalan Embong Tanjung no. 33, dengan ciri-ciri denah simetris, atap perisai, dan karakteristik bangunannya terbuka. Gaya arsitektur setelah tahun 1900 contohnyaada pada rumah di Jalan Embong Ploso no. 19, dan Jalan Embong Kemiri no. 17. Pada kedua rumah tersebut teramati elemen penting arsitekturnya seperti gevel, ventilasi, bentuk bangunan cenderung ramping dan berorientasi utara-selatan.Untuk gaya arsitektur setelah tahun 1920 seperti pada rumah tinggal di Jalan Kayun no. 32 dan no. 42-44.

Lebih jauh, identifikasi untuk gaya arsitektur bangunan rumah tinggal di kawasan Simpang juga dilakukan berdasarkan kajian dari Handinoto (2012). Kajian tersebut mengenai "arsitektur transisi" yang berkembang di Indonesia dari akhir abad 19 ke awal abad 20. Gaya arsitektur transisi atau peralihan berkembang sekitar tahun 1890 sampai 1915. Secara umum gaya arsitektur peralihan mirip dengan arsitektur "Indische Empire" dengan ciri bentuk simetri penuh, adanya teras depan dan teras belakang, ruang utama, dan kadangkala masih terdapat paviliun (bangunan samping) terutama untuk rumah-rumah berukuran besar. Hal yang membuat arsitektur peralihan terlihat berbeda dengan "Indische Empire" adalah tidak adanya pilar bergaya Yunani atau Romawi sebagai ciri khasnya.

Beberapa rumah tinggal kolonial di kawasan Simpang yang didokumentasi dalam studi 
initerindikasimemperlihatkan pula gaya arsitektur transisi atau peralihan (Tabel 2.). Dipahami dari sejarah perkembangan kawasan dan perkembangan arsitektural di Surabaya, indikasi tersebut sangat dimungkinkan. Simpang menjadi bagian kawasan besar yang dalam perencanaan pemerintah Belanda di Surabaya digunakan untuk pengembangan perumahan (daerah Keputran). Pengembangan daerah ini ada di bawah kekuasaan Bowmaatschapij Keputran di tahun 1888 (Tillema, 1921: 925 dalam Handinoto, 1996). Bowmaatschapij sendiri adalah sejenis departemen pekerjaan umum sipil (dari BOW - Burgerlijke Openbare Werken) yang bertugas untuk pengerjaan rumah-rumah dinas. Catatan menarik di sini adalah Bowmaatschapij di bawah pemerintah kolonial dalam pelaksanaan kerjanya tidak mengabaikan kedudukan ahli bangunan lokal (Soekiman, 2014). Hal inilah yang tampaknya menjadi dasar perkembangan arsitektur kolonial di Indonesia (juga Surabaya) setelah 1900 memunculkan bentuk atau gaya yang khas, sebagai hasil adaptasi arsitektur dengan lingkungan lokal.Meskipun kemudian pengembangan perumahan di daerah initidak begitu sukses dilakukan oleh Bowmaatschapij Keputran, daerah sekitar Simpang masih terus berkembang. Sepertinya kebijakan menjual tanah per kaveling oleh Bowmaatschapij Keputran setelah mengalami kegagalan menjadi salah satu faktor pendukungnya. Faktor lain adalah tinggal di daerah perumahan pada masa itu menjadi semacam mode kelas sosial-ekonomi tinggi. Bukti perkembangan kawasan ini kemudian dapat dilihat dari jalan-jalan yang ada yang diberi nama Embong, misalnya Embong Gayam, Tanjung, dan sebagainya (Handinoto, 1996).

Gambaran makin berkembangnya kawasan
Simpang juga dapat dilihat dari keberadaan rumah tinggal dengan arsitektur kolonial modern. Sebagaimana telah disebutkan sebelumnya, rumah tinggal dengan arsitektur kolonial modern di lokasi studi ini dapat ditemukan di Jalan Kayun no. 32 dan no. 42-44. Gaya arsitektur kolonial modern sendiri berkembang sekitar tahun 1915-1940. Secara umum gaya arsitektur ini dijelaskan menjauhi pengaruh "Indische Empire", misalnya tidak terlalu memperhatikan simetrisme, lebih kreatif dan bervariasi, menggunakan bahan bangunan baru dari beton, dan pemakaian bahan kaca terutama untuk jendela (Handinoto, 2012). Karakteristik arsitektur modern tersebut juga tampak pada dua rumah tinggal yang ada di Jalan Kayun. Keadaanitu menunjukkan bahwa berkembangnya permukiman juga berpengaruh pada perkembangan aspek arsitekturalnya. Berkembangnya kawasan Simpang berpengaruh pada arsitektur bangunan yang ada di dalamnya. Handinoto (1996) juga telah menjelaskan bahwa arsitektur berkembang sejalan dengan perkembangan kota, meskipun periodisasi perkembangannya tidak selalu sama karena arsitektur memiliki gaya tersendiri.

\section{Perubahan PadaBangunan}

Keberadaan rumah tinggal masa kolonial yang ada di kawasan Simpang menunjukkan pola-pola perubahan sebagai dampak pengaruh perkembangan dan pembangunan kota. Paling utama adalah perubahan secara keseluruhan dari struktur bangunan, dalam hal ini rumah tinggal masa kolonial telah berganti bangunan baru. Salah satu contoh perubahan struktur bangunan secara keseluruhan selama rentang waktu 2010-2015 terjadi pada rumah tinggal di Jalan Embong Kenongo,

Tabel 2. Rumah tinggal yang terindikasi bergaya arsitektur transisi

\begin{tabular}{|c|c|c|c|}
\hline No & Nama Jalan & Rumah tinggal & Ciri Arsitektur Peralihan* \\
\hline 1 & Kayun & No. $16-18$ & $\begin{array}{l}\text { Denah simetris, gevel, kesan menara pada pintu } \\
\text { masuk, atap pelana dan perisai, ventilasi (bahan } \\
\text { kayu) }\end{array}$ \\
\hline \multirow[t]{2}{*}{2} & Embong Tanjung & No. $24-28$ & $\begin{array}{l}\text { Gevel, atap pelana dan perisai, ventilasi(bahan } \\
\text { kayu) }\end{array}$ \\
\hline & & No. $27-29$ & $\begin{array}{l}\text { Gevel, kesan menara pada pintu masuk, atap } \\
\text { perisai, ventilasi (bahan kayu) }\end{array}$ \\
\hline 3 & Embong Ploso & No. 19 & $\begin{array}{l}\text { Gevel, kesan menara pada pintu masuk, atap } \\
\text { pelana dan perisai, ventilasi (bahan kayu) }\end{array}$ \\
\hline 4 & Embong Kemiri & No. 17 & $\begin{array}{l}\text { Gevel (dengan hiasan), atap pelana dan perisai, } \\
\text { ventilasi (bahan kayu) }\end{array}$ \\
\hline
\end{tabular}

( ${ }^{*}$ Sumber: Handinoto, 2012) 
yang telah berganti menjadi bangunan dengan arsitektur baru. Perubahan secara keseluruhan diduga pula akan terjadi pada tiga rumah tinggal yang kondisinya saat ini tidak terawat, atau tampaknya sengaja dibiarkan rusak untuk kemudian dapat diganti dengan bangunan baru, yaitu rumah di ujung timur Jalan Embong Ploso (juga sepanjang jalan Kaayun) dan dua rumah di Jalan Embong Kemiri.

Telah dijelaskan sebelumnya bahwa status bangunan-bangunan rumah tinggal maupun kawasan Simpang sendiri yang menjadi bahan studi ini bukan merupakancagar budaya. Tampaknya status ini menjadi salah satu faktor berpengaruh terhadap keberadaan bangunannya. Status yang "tidak terlindungi" iniakan mempermudah perlakuan perubahan atau bahkan penghilangan bangunan rumah tinggal tersisa. Sebagai contoh dapat dipahami dari kasus perobohan rumah tinggal di Jalan Kayun no. 4-6 (Sinagoge). Meskipun telahmasuk daftar bangunan "Diduga Bangunan Cagar Budaya" berdasarkan SK Dinas Kebudayaan dan Pariwisata Surabaya No. 646/1654/436.6.14/2009 (Sinagoge Surabaya Dihancurkan, Sjarikat Poesaka Soerabaia Protes Keras, http://nusantara.rmol.co/ $\mathrm{read} / 2013 / 05 / 28 / 112362)$, bangunan rumah tinggal tersebut tetap saja mengalami perobohan di tahun 2013.

Perubahan dan permasalahan yang terjadi pada kawasan Simpang dan bangunan rumah tinggal yang ada di dalamnya, tampaknya juga menjadi permasalahan yang di kota-kota yang memiliki sumberdaya serupa. Kwanda (2005) telah menjelaskan bahwa perubahan kawasandengan latar belakang kolonial menjadi permasalahan yang umum terjadi seiring dengan perkembangan dan pembangunan kota. Hal ini karena kawasan pusat kota menjadi jalan masuknya ide-ide perubahan yang disesuaikan dengan tuntutan perkembangan jaman dan modernisasi (Damayanti \& Handinoto, 2005). Di Simpang, ide-ide perubahan dapat dilihat pada kawasannya dan bangunan yang ada. Simpang saat ini telah berkembang menjadi salah satu pusat kegiatan ekonomi dan bisnis di Surabaya, dengan sebaran gedung-gedung perkantoran, apartemen, mall dan hotel di sekitarnya. Rumah tinggal dengan gaya arsitektur kolonial sangat mungkin dianggap tidak lagi sesuai dengan modernisasi dan kemajuan yang telah berkembang di sekitar kawasan, sehingga kemudian bangunannya dirubah dengan gaya arsitektur baru mengikuti tren yang ada. Hal mengenai perubahan kota telah pula ditegaskan oleh Stutterheim (1948: 1-9 dalam Karyono, 2002) bahwa tren pembangunan kota cenderung mengedepankan perubahan dan penggantian dengan unsur-unsur baru atau modern.

Salah satu hal berpengaruh pada terjadinya perubahan bangunan di sebuah kawasan bersejarah adalah kegagalan dalam perencanaan dan perancangan kota. Dalam hal ini, permasalahan kemudian muncul karena penelusuran terhadap sejarah perkembangan kawasan kota di masa lalu tidak dilakukan sehingga konsep perencanaan pembangunan kota menjadi kurang terarah (Kwanda, 2005).Hal tersebut tampaknya pula terjadi di kawasan Simpang. Latar belakang sejarah berdirinya kawasan Simpang dengan beragam corak kehidupannya menjadikan kawasan ini sesungguhnya sebagai salah satu citra kawasan penting bagi Kota Surabaya. Namun perkembangan dalam kehidupan ekonomi, sosial, dan budaya, membawa pengaruh dalam dinamika kawasan tersebut. Perubahan atau perobohan, tidak hanya pada gaya arsitektur bangunan, tapi juga keseluruhan bangunan serta pola dan tata ruang kawasan, dapat menghilangkan identitas serta karakter khas kawasan Simpang sebagai suatu kawasan dengan nilai-nilai sejarah dan budaya yang penting. Moordiati (2005) telah menegaskan bahwa tata ruang wilayah sebuah kota memiliki proses sejarah panjang dalam pembentukannya, serta masyarakat sebagai salah satu unsur penting dalam perkembangan sebuah kawasan kota. Setiap perubahan yang terjadi kemudian pada tinggalan-tinggalan budaya yang ada di dalam suatu kawasan kota dapat mengaburkan jejak-jejak sejarah, pemikiran dan konsep yang melatarbelakangi keberadaan tinggalan budaya tersebut.

\section{Penutup \\ Simpulan}

Sebagian besar bangunan rumah tinggal di kawasan Simpang yang menjadi bahan studi dalam tulisan ini terindikasi bergaya arsitektur transisi atau peralihan, yang berkembang antara tahun 1890 sampai tahun 1915. Selain itu terindikasi pula bangunan dengan gaya arsitektur yang berkembang sebelum tahun 1900, serta gaya arsitektur modern (setelah tahun 1920). Temuan ini menunjukkan bahwa kawasan Simpang dapat menjadi 
salah satu contoh khusus mengenai perkembangan gaya arsitektur bangunan rumah tinggal kolonial yang ada di Kota Surabaya. Temuan lain yang menjadi perhatian khusus adalah keberadaan bangunannya yang rentan terhadap kerusakan, perobohan atau penghilangan, berkaitan dengan statusnya yang bukan bagian dari cagar budaya dan perkembangan kawasan Simpang sendiri.

\section{Daftar Pustaka}

Damayanti, R dan Handinoto. 2005. Kawasan "Pusat Kota" Dalam Perkembangan Sejarah Perkotaan di Jawa. Dimensi Teknik Arsitektur, 33 (1): 34-42.

Handinoto. 1993. Arsitek G. C. Citroen dan Perkembangan Arsitektur Kolonial Belanda di Surabaya (19151940). Dimensi 19: 1-16

Handinoto. 1996. Perkembangan Kota dan Arsitektur Kolonial Belanda di Surabaya (1870-1940). Yogyakarta: Andi.

Handinoto.1998. Perubahan Besar Morpologi Kotakota di Jawa Pada Awal dan Akhir Abad ke-20. Dimensi Arsitektur, 26: 1-14.

Handinoto. 2012. Arsitektur dan Kota-kota di Jawa pada Masa Kolonial. Yogyakarta: Graha Ilmu.

Handinoto dan Hartono, S. 2007. Surabaya Kota Pelabuhan ('Surabaya Port City'). Dimensi Teknik Arsitektur, 35 (1): 88-99.

Karisztia, A. D., Pangarsa, G.W., dan Antariksa. 2008. Tipologi Façade Rumah Tinggal Kolonial Belanda Di Kayu Tangan-Malang. Arsitektur e-Journal, I(2): 64-76.

Karyono. 2002. Kota Salatiga: Studi Tentang Perkembangan Kota Kolonial 1917-1942. Yogyakarta. Universitas Gajah Mada. Tesis tidak dipublikasikan.

\section{Saran}

Dari aspek arsitektur, perlu dilakukan studi lebih lanjut untuk mendapatkan gambaran secara detil mengenai gaya arsitektur bangunan rumah tinggal yang ada di kawasan Simpang. Dipahami dari latar belakang sejarah perkembangan kawasan Simpang, perlu dilakukan kajian terkait dengan status kawasan dan rumah tinggal yang ada di dalamnya sebagai cagar budaya.

Kwanda, T. 2005. Potensi dan Masalah Kota Bawah Surabaya Sebagai Kawasan Pusaka Budaya. Dalam F. Colombijn, M. Barwegen, P. Basundoro, dan J. A. Khusyairi (Eds.), Kota Lama Kota Baru. Yogyakarta: Ombak.

Moordiati. 2005. Masyarakat Kota dalam Sejarah Surabaya 1930-1960. Dalam F. Colombijn, M. Barwegen, P. Basundoro, dan J. A. Khusyairi (Eds.), Kota Lama Kota Baru. Yogyakarta: Ombak.

Soekiman, D. 2014. Kebudayaan Indis Dari Zaman Kompeni sampai Revolusi. Depok: Komunitas Bambu.

Sukendar, H., Simanjuntak, T., Eriawati, Y., Suhadi, M., Prasetyo, B., Harkantiningsih, N., dan Handini, R. (eds.). 1999. Metode Penelitian Arkeologi. Puslit Arkenas: Jakarta.

Sulyanto, B. 2003. Upaya Melestarikan Benda dan Bangunan Cagar Budaya di Kota Surabaya, (Diunduh online), (www.ArsitekturIndis.com, diakses 19 Februari 2009).

Sinagoge Surabava Dihancurkan, Sjarikat Poesaka

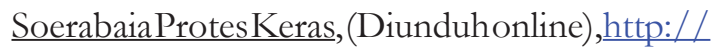
nusantara.rmol.co/read/2013/05/28/112362, diakses 11 Agustus 2015. 